\title{
Evaluation Of Leprosy Management Program Implementation In Karang Penang Health Center, Sampang District, Madura
}

\author{
Reny Nugraheni*, Meira Kusuma Wardani \\ Institut Ilmu Kesehatan Bhakti Wiyata, Kediri, Indonesia \\ * reny.nugraheni@iik.ac.id
}

\begin{abstract}
Leprosy is an infectious disease that causes very complex problems. The prevalence of leprosy in Karang Penang Health Center, Sampang District in the last 3 years has fluctuated by 35 cases in 2015, 23 cases in 2016, and 55 cases in 2017. This study aims to evaluate implementation of leprosy management program in Karang Penang Health Center, Sampang District, Year 2017. This research uses Mix Methods by combining qualitative (In Depth Interview) and quantitative (Descriptive Survey) methods with Sequential Explanatory models. The sample in this study was leprosy surveillance data, while the informants consisted by two key informants and four main informants. Data processing in this research is quantitative data processing. The results showed that for 'aspects of health status produced' there was only one aspect which has fulfilled national standard, namely cure rate (MB and $\mathrm{PB})$; ' aspects of service quality that have been implemented' have been achieved; 'aspects of quantity of services provided' (ICF activities, drug administration according to dosage, and home visits), which are not optimal because this program runs only for affordable areas and there are still limited resources and facilities that do not support; 'aspects of community attitudes' that strongly support this program to be implemented, but community stigma is still low; 'aspects of available resources' have not been good due to limited human resources and facilities; and 'aspects of costs source' used are from the government. It is hoped that health agencies will approach community and religious leaders to change the community's stigma and provide motor vehicle facilities for leprosy officers to carry out this program very well.
\end{abstract}

Keywords : Evaluation, Management, Leprosy 


\section{STRADA Jurnal Ilmiah Kesehatan}

DOI: $10.30994 /$ sjik.v9i2.317

ISSN: 2252-3847 (print); 2614-350X (online)

Vol.9 No.2 November 2020 Page.879-885

\section{BACKGROUND}

Contagion of leprosy can occur when Mycobacterium leprae is solid (living) out of patient's respiratory droplet and enters other healthy human bodies through the respiratory tract, and occurs when there is direct contact over and over for a long time (Health Ministry of Republic of Indonesia, 2016).

According to WHO (2017), people with leprosy in Indonesia are ranked third $(16,826)$ in the World, after India $(135,485)$ and Brazil $(25,218)$. Based on the data from General Directorate of P2P Health Ministry of Republic of Indonesia (2017) shows that the highest prevalence of leprosy in Indonesia is in East Java Province. East Java was also included in High Endemic area of leprosy in 2013-2017. Explained that the number of leprosy cases in Sampang District, Madura, East Java in 2017 was 311 cases.

Based on these data, it is necessary to evaluate implementation of leprosy management program. Evaluation (Assessment) is a process for determining value or success levels of implementing a program in achieving its stated goals, or a process that is orderly and systematic in comparing the results which are achieved with benchmarks or criteria that have been determined, and continued with drawing conclusions and providing suggestions that can be done at each stage of program implementation (Azwar, 2010). This research identifying achievement of health status produced, including: the number of new cases of leprosy, the number of leprosy prevalence, leprosy cure rates, leprosy grade 2 disability; quality of services provided, including: reliability, responsiveness, assurance, empathy, and tangible; quantity of services produced, including: ICF activities, visits to patients' homes, and giving of drugs according to dosage; communities attitude towards health programs, including: affective component, cognitive component, conative component; available resources, including: funds sources, energy sources, and facilities sources; costs which are used, including: government, private parties, communities, grants/foreign loans in Karang Penang Health Center, Sampang District, Madura

\section{METHODS}

This research uses Mix Methods with Sequential Explanatory Model. Sequential Explanatory Model is a method that is used sequentially, the first step in this model is to collect data and quantitative data analysis, then proceed with qualitative data collection and analysis, and this model aims to strengthen quantitative research (Creswell, 2016). Quantitative method which is used in this research is descriptive survey method. This research was conducted in Karang Penang Health Center, Sampang District, Madura, East Java. Time of this study was conducted in January to August 2017. Population and sample in this study are all data of leprosy surveillance in Karang Penang Health Center, Sampang District in 2017. The sampling technique was purposive sampling, with six informants. The results of this study were analyzed using univariate data analysis which aims to explain or describe quantitative data from each research variable. Univariate analysis is a data analysis obtained from data collection and can be presented by frequency distribution tables or graphs (Tribowo and Mitha, 2015). Univariate analysis was carried out to see frequency distribution of health status produced, including the number of new cases found, rate of disability grade 2 , cure rate, and prevalence rate. 


\section{STRADA Jurnal Ilmiah Kesehatan}

DOI: $10.30994 /$ sjik.v9i2.317

ISSN: 2252-3847 (print); 2614-350X (online)

Vol.9 No.2 November 2020 Page.879-885

\section{RESULTS AND DISCUSSION}

\section{A. Univariate Analysis}

\section{Characteristics of Leprosy Surveillance Data}

Table V.1 Characteristics of Leprosy Surveillance Data

\begin{tabular}{clc}
\hline No & \multicolumn{1}{c}{ Leprosy Surveillance Data Classification } & Case Results \\
\hline 1. & Number of new cases found in 1-year period & 55 \\
2. & Number of new cases with grade 2 disabilities in 1-year period & 8 \\
3. & Number of new MB cases that completed 12 doses in 12-18 months in 2017 & 27 \\
4. & Number of new PB cases that completed 6 doses in 6-9 months in 2017 & 1 \\
5. & Number of leprosy cases in 2017 & 55 \\
6. & Number of new MB cases that are still undergoing treatment until 2018/have & 17 \\
& not been completed 12 doses in 12-18 months in 2017 & 2 \\
7 & Number of new MB cases dropped out in 2017 & \\
\hline
\end{tabular}

\section{Informants Characteristics}

\section{a. Key Informants}

Table V.2 Key Informants

\begin{tabular}{cccccc}
\hline No & Initial & Age & Gender & Occupation & Education \\
\hline 1. & Sc & 40 yo & Male & $\begin{array}{c}\text { Head of Health } \\
\text { Center } \\
\text { PJ P2 Leprosy }\end{array}$ & $\begin{array}{c}\text { Bachelor of } \\
\text { Nursing } \\
\text { Diploma } 3 \text { in } \\
\text { Nursing }\end{array}$ \\
\hline
\end{tabular}

\section{b. Main Informants}

Tabel V.3 Main Informants

\begin{tabular}{|c|c|c|c|c|c|c|}
\hline No & Initial & Age & Gender & Occupation & Education & Criteria \\
\hline 1. & $\mathrm{Mt}$ & 40 уо & Male & Farmer & $\begin{array}{l}\text { Middle } \\
\text { School }\end{array}$ & $\begin{array}{c}\text { Disability } \\
\text { Grade } 2\end{array}$ \\
\hline 2. & $\mathrm{Sn}$ & 50 уо & Female & Housewife & $\begin{array}{c}\text { Primary } \\
\text { School }\end{array}$ & $\begin{array}{c}\text { New } \\
\text { Discovered }\end{array}$ \\
\hline 3. & Ms & 40 уо & Female & Housewife & $\begin{array}{c}\text { Primary } \\
\text { School }\end{array}$ & PB \\
\hline 4. & $\mathrm{Mh}$ & 27 уо & Female & Female Workers & $\begin{array}{l}\text { Middle } \\
\text { School }\end{array}$ & MB \\
\hline
\end{tabular}

\section{Health Status Produced}

Tabel V.4 Case Finding Figures Variable, Disability Figures Grade 2, Cure Rate RFT Rate MB dan RFT Rate PB, and Prevalence Rate

\begin{tabular}{|c|c|c|c|c|c|c|c|c|c|c|}
\hline \multirow{4}{*}{ No } & \multirow{3}{*}{\multicolumn{2}{|c|}{ New Case Finding Figures }} & \multirow{3}{*}{\multicolumn{2}{|c|}{ Disability Figures Level 2}} & \multirow{2}{*}{\multicolumn{4}{|c|}{ Cure Rate }} & \multirow{3}{*}{\multicolumn{2}{|c|}{ Prevalence Rate }} \\
\hline & & & & & & & & & & \\
\hline & & & & & \multicolumn{2}{|c|}{ RFT Rate MB } & \multicolumn{2}{|c|}{ RFT Rate PB } & & \\
\hline & $\begin{array}{c}\text { Case Finding } \\
\text { Figures } \\
\text { Variable }\end{array}$ & Results & $\begin{array}{c}\text { Case Finding } \\
\text { Figures } \\
\text { Variable }\end{array}$ & Results & $\begin{array}{c}\text { Case Finding } \\
\text { Figures } \\
\text { Variable }\end{array}$ & Results & $\begin{array}{c}\text { Case Finding } \\
\text { Figures } \\
\text { Variable }\end{array}$ & Results & $\begin{array}{c}\text { Case Finding } \\
\text { Figures } \\
\text { Variable }\end{array}$ & Results \\
\hline 1. & $\begin{array}{l}\text { Number of new } \\
\text { cases found in } 1- \\
\text { year period } \\
(2017)\end{array}$ & 55 Cases & $\begin{array}{l}\text { Number of new } \\
\text { cases with grade } \\
2 \text { disabilities in } \\
\text { 1-year period } \\
(2017)\end{array}$ & 8 Cases & $\begin{array}{l}\text { Number of new } \\
\text { MB cases that } \\
\text { completed } 12 \\
\text { doses in } 12-18 \\
\text { months in } 2017\end{array}$ & 27 Cases & $\begin{array}{l}\text { Number of new } \\
\text { PB cases that } \\
\text { completed } 6 \\
\text { doses in } 6-9 \\
\text { months in } 2017\end{array}$ & 1 Case & $\begin{array}{ll}\text { Number } & \text { of } \\
\text { leprosy cases in } \\
2017\end{array}$ & 55 Cases \\
\hline \multirow[t]{2}{*}{2.} & $\begin{array}{l}\text { Total population } \\
\text { in } 2017\end{array}$ & $\begin{array}{c}69.244 \\
\text { Residents }\end{array}$ & $\begin{array}{l}\text { New cases found } \\
\text { in the same } \\
\text { period }\end{array}$ & 55 Cases & $\begin{array}{l}\text { Total number of } \\
\text { new MB cases } \\
\text { that began MDT } \\
\text { in the same year } \\
\text { of cohort period } \\
\text { in } 2017\end{array}$ & 28 Cases & $\begin{array}{l}\text { Total number of } \\
\text { new PB cases } \\
\text { that began MDT } \\
\text { in the same year } \\
\text { of cohort period } \\
\text { in } 2017\end{array}$ & 1 Case & $\begin{array}{l}\text { Total population } \\
\text { in } 2017\end{array}$ & $\begin{array}{c}69.244 \\
\text { Residents }\end{array}$ \\
\hline & Achievement & $79,42 \%$ & Achievement & $15 \%$ & Achievement & $96 \%$ & Achievement & $100 \%$ & Achievement & 7,94 \\
\hline
\end{tabular}




\section{STRADA Jurnal Ilmiah Kesehatan}

DOI: $10.30994 /$ sjik.v9i2.317

ISSN: 2252-3847 (print); 2614-350X (online)

Vol.9 No.2 November 2020 Page.879-885

\section{Quality of Service Provided}

a. Reliability

"....The time is not long, just for a short time, I was only checked for a while, then I was given the medicine according to my dose, and I went home... I was send to Karang Penang Health Center and I was also explained that I had leprosy until I understood...

(Mh, 27yo, Leprosy MB, Female Worker)

b. Responsiveness

".... The time is not long, I was only checked for a while, then I was given the medicine according to my dose, and I went home..."

(Mh, 27yo, Leprosy MB, Female Worker)

c. Assurance

".... The health officer was very polite, he wasn't afraid of my illness..."

(Mh, 27yo, Leprosy MB, Female Worker)

d. Empathy

".... The health officer never forced me to take a treatment, but he explained to me about the consequences that I would feel if I do not take the treatment, he also gave me some medicines that I needed...

e. Tangible

(Msh, 27yo, leprosy MB, Female Worker)

"...Yes, his appearance was very neat, just like most health officers...."

\section{Quantity of Services Produced}

(Mt,40yo, Farmer)

a. ICF Activity

“...There wasn't Health Center Officer who came here, I went to Health Center regularly to check me up and take my medicines..."

(Mh, 27yo, Female Worker)

b. Visit to Patient Home

"...Yes, The Doctor (Leprosy Nurse) had been here before and he checked me up. He also checked my house's condition, then he send me to a Health Center in Sampang, but it wasn't regularly, and he was the one who came here, and now you're (Researcher) also coming here..."

(Mt, 40yo, Farmer)

c. Giving of Prophylactic Contra Medication According to Dosage and Age

"...Yes, I took a treatment regularly, when I had three medicines left, I went to The Health Center to take my medicines. But I didn't get my medicine by myself regularly, sometimes my mother or my sister got it for me..."

d. Community Attitude Towards Health Programs

(Ms, 27yo, Female Worker)

"...For me personally, I support this Health Program because Health Center help me a lot to recover my illness, but there are some neighbors who don't want to stay close to me. They said that they are afraid of contracting my illness. They also said, I'm a bit smelly and creepy..."

(Mt,40yo, Farmer) 


\section{STRADA Jurnal Ilmiah Kesehatan}

DOI: $10.30994 /$ sjik.v9i2.317

ISSN: 2252-3847 (print); 2614-350X (online)

Vol.9 No.2 November 2020 Page.879-885

\section{Available Resources}

a. Funds Source

"...That was free, I got my medicines from Health Center for free. I only paid registration fee, then there were no more fees..."

(Ms, 40 yo, Housewife and Sn, 50yo, Housewife)

b. Health Resources

"...All the medicines are free, and this health program is also free because this program is from the central government, so there are no fees charged to patients or families..."

c. Facilities Source

(Sc, 40yo, Bachelor of Nurse, Head of Health Center)

"...The facilities here are like this, leprosy room is in one place with Tuberculosis room, the building here is appropriate to use according to the standard, medical facilities such as examination tools are available, and medicines are also available..."

(Sc, 40yo, Bachelor of Nurse, Head of Health Center)

\section{Costs Used}

"...Yes, it was from the government. All examination tools, medicines, and health program costs were paid by the government..."

(Mk, 33yo, Diploma 3 in Nurse, PJ P2 Leprosy)

\section{Evaluation of Leprosy Prevention Program Implementation in Karang Penang Health Center}

1. Health Status Provided

New Case Discovery Rate $(\mathrm{CDR}=$ Case Detection Rate $)$ has not met national indicator standard because this new case discovery activity is not going well, this is in line with research by Heri Purwanto (2013), results of new leprosy case discovery in Lampung were 9.02 cases and it can be concluded that P2 Leprosy Program has not been successful because new leprosy case discovery activity is only carried out passively, so the results have not been maximized. At Grade 2 Disability Rate, the target of P2 leprosy is still not reached, this is in line with Kamal Muhammad's research (2015) who explains that the high proportion of grade 2 disabilities in Sampang District is around 11.6\%. For cure rate (RFT $=$ Release From Treatment), MB RFT Rate and PB RFT Rate have met national indicator standard that is $\geq 90 \%$ of cases. Prevalence Rate (PR) is a number that shows the magnitude of problems in an area and determines the workload and is also used as an evaluation tool.

2. Service Quality Provided

Reliability, Responsiveness, Assurance, Empathy, and Tangible have been reached. This is in line with Sabrina's research (2015) which states that reliability is a health officer accuracy in providing services to patients, responsive is a health officers' response when receiving patient complaints as well as their quickness in providing services to patients. Confidence is a guarantee for consumers including ability, politeness, and trustworthiness to health officers. In its development, guarantees including knowledge and abilities, while empathy is giving more attention to patients and approach them in order to know their willingness and finally patients want to seek treatment, and this dimension also relates to physical facilities attractiveness, 


\section{STRADA Jurnal Ilmiah Kesehatan}

DOI: $10.30994 /$ sjik.v9i2.317

ISSN: 2252-3847 (print); 2614-350X (online)

Vol.9 No.2 November 2020 Page.879-885

equipment, and health officers appearance, and all of them are tangible evidence of services provided to patients.

3. Service Quantity Produced

ICF (Index Case Finding) is not going well because health officers have not visited patients until now to carry out ICF activities and these activities are only done for patients who live in affordable area. Home visit to patients have been conducted, but it is done only for patients who live in affordable area. This is in line with research by Siti Farhan (2013) which states that health officers have a very close relationship with patients. Giving of 'counter prophylactic drugs according to dose and age' has been conducted, but it is only given in Karang Penang Health Center. This is in line with Horne's research (2016) which states that there are different point of views about health, in terms relationship between patients and health officers.

4. Community Attitudes Towards Health Programs

The community has supported this health program, but their stigma against leprosy and its sufferers is still low. It is due to culture and beliefs according to religion influence which are still thick about leprosy. This is in line with Mulyanti's research (2016) which stated that attitude is an expression of feelings that express happy or unhappy, like or dislike, and agree or disagree towards an object.

5. Available Resources

Funds source for this health program is from the central government, or it can be said that this program is free. This is in line with a research by Rahmawati (2007) which stated that funds source for health program is from state budget (APBN) and Regional Revenue and Expenditures Budget (APBD) which are allocated for health programs. Health officers who handle leprosy sufferers is a nurse, because there isn't many doctors, and if there are some doctors, they don't want to handle leprosy sufferers. This is in accordance with a research by East Java Health Office (2008) which states that health officers' resources are the main driving factors, so that health human resources quality will determine success of the entire health development process. Indicators of source facilities have not occurred maximally or in accordance with needs, this is due to difficulties in proposing required facilities. This is also in line with research by East Java Health Office (2008) which states that the rapid development of health sector in providing health facilities and infrastructure.

6. Cost Used

Funds source which is used for leprosy prevention programs implementation is from the central government. This is in line with a research by Rahmawati (2007) which states that any costs used for health programs come from state budget and regional budget which are allocated for health programs

\section{CONCLUSION}

There is only one Health Status Provided indicator that have met national standard, namely cure rate, Service Quality Provided in Karang Penang Health Center has been fulfilled, Service Quantity Produced has been done by PJ P2 leprosy officers but it has not been maximized, Community Attitudes Toward Health Programs are very supportive but their stigma against people with leprosy is still bad, Available Resources such as facilities and funds in Karang Penang Health Center have not been fulfilled, Cost Used for this health program is from the government (state budget and regional budget). 


\section{STRADA Jurnal Ilmiah Kesehatan}

DOI: $10.30994 /$ sjik.v9i2.317

ISSN: 2252-3847 (print); 2614-350X (online)

Vol.9 No.2 November 2020 Page.879-885

\section{REFERENCE}

Annisa Q.N, dkk, 2012. Profil Penderita Penyakit Kusta di Rumah Sakit Kusta Kediri periode Januari 2010 sampai Desember 2010, Jurnal Kesehatan, Volume 8, No. 2, Desember 2012. Fakultas Kedokteran Universitas Muhammadiyah Malang.

Azwar Azrul, 2010.Pengatar Administrasi Kesehatan Edisi ke 3 Jakarta Binarupa Aksara, Jakarta 2010.

Hera J.G, 2015. Hubungan Pengetahuan dan Sikap Masyarakat terhadap Stigma Penyakit Kusta. Jurnal Agromed Unik, Vol. 2, No. 3, Agustus 2015. 326 - 332.

Kamal M, dkk, 2015.Kurangnya Konseling dan Penemuan Kasus Secara Pasif mempengaruhi Layanan Kecacatan Kusta Tingkat II di Kabupaten Sampang, Jurnal Berkala Epidemiologi, Vol. 3, No. 3. September 2015 : 290 - 303.

Kementrian Kesehatan Republik Indonesia, Perdoman Nasional Program Pengendalian Penyakit Kusta. Direktorat Jendral Pengendalian Penyakit dan Penyehatan Lingkungan Kementrian Kesehatan Republik Indonesia, Jakarta. 2016.

Mulyanti K. Dan Fachrurozi A, 2016. Analisis sikap dan perilaku masyarakat terhadap pelaksanaan program bank sampah (studi kasus masyarakat kelurahan bahagia bekasi utara).Jurnal ilmiah ekonomi manajemen dan kewirausahaann "Optimal", Vol. 10, No. 2 - September 2016 185-198.

Notoatmodjo S, 2012. Metodologi penelitian kesehatan. Jakarta: Rineka Cipta, 2012.

Purwanto Heri, 2013. Cara Penemuan Penderita Kusta Baru dan Tingkat Kecatatan di Propinsi Lampung. Jurnal Kesehatan Vol. IV No. 2 Oktober 2013 hlm. 371 - 380.

Puskesmas Karang Penang Kabupaten Sampang 2018. Profil Puskesmas Karang Penang Kabupaten Sampang.

Rahmawati, N.A, 2007. Analisis Pembiayaan Kesehatan Bersumber Pemerintah di Kabupaten Bogor. Jurnal Kesehatan Masyarakat Nasional Vol. 2, No. 1 Agustus 2007.

Sabrina, Q, 2015. Pelaksanaan Program Jaminana Kesehatan Nasional (JKN) dalam Peningkatan Kualitas Pelayanan Kesehatan di RSU Haji Surabaya Vol. 3 No.2 Mei - Agustus 2015 ISSN 2303 - 341X.

Triwibowo C dan Mitha E.P, 2015. Pengantar dasar ilmu kesehatan masyarakat: untuk mahasiswa kesehatan masyarakat, keperawatan, dan kebidanan. Nuha Medika, 2015. $6021547713,9786021547717$.

World Health Organization, 2017. Prevelence of Leprosy (internet) Geruna : WHO. 2017 (diakses tanggal 27 april 2018). Tersedia dari http://who.int/lep/

World Health Organization, Buku Pedoman Nasional Program Pengendalian Pengadaan Penyakit dan Penyerahatan Lingkungan Kementrian Kesehatan Republik Indonesia, Jakarta 2016 